\title{
Heterologous effects of infant BCG vaccination: potential mechanisms of immunity
}

\author{
Egle Butkeviciute ${ }^{1}$, Christine E Jones ${ }^{2,3}$ \& Steven G Smith*,1 \\ ${ }^{1}$ Department of Immunology \& Infection, Faculty of Infectious \& Tropical Diseases, London School of Hygiene \& Tropical Medicine, \\ Keppel Street, London, WC1E 7HT, United Kingdom \\ ${ }^{2}$ Faculty of Medicine \& Institute for Life Sciences, University of Southampton \& University Hospital Southampton NHS Foundation \\ Trust, Tremona Road, Southampton, SO16 6YD, United Kingdom \\ ${ }^{3}$ Paediatric Infectious Diseases Research Group, St George's, University of London, Cranmer Terrace, London, SW17 ORE, United \\ Kingdom \\ *Author for correspondence: Steven.Smith@|shtm.ac.uk
}

The current antituberculosis vaccine, BCG, was derived in the 1920s, yet the mechanisms of BCG-induced protective immunity and the variability of protective efficacy among populations are still not fully understood. BCG challenges the concept of vaccine specificity, as there is evidence that BCG may protect immunized infants from pathogens other than Mycobacterium tuberculosis - resulting in heterologous or nonspecific protection. This review summarizes the up-to-date evidence for this phenomenon, potential immunological mechanisms and implications for improved childhood vaccine design. BCG induces functional changes in infant innate and adaptive immune compartments, encouraging their collaboration in the first year of life. Understanding biological mechanisms beyond heterologous BCG effects is crucial to improve infant protection from infectious diseases.

First draft submitted: 18 January 2018; Accepted for publication: 27 April 2018; Published online: 17 August 2018

Keywords: BCG $\bullet$ childhood immunization $\bullet$ heterologous vaccine effects $\bullet$ humoral responses $\bullet$ infant immunity $\bullet$ innate memory $\bullet$ monocytes $\bullet$ NK cells $\bullet T$ cells $\bullet$ trained immunity

The BCG is a live attenuated strain of Mycobacterium bovis and is the only currently licensed vaccine against TB. It is routinely administered to infants at or shortly after birth in regions where TB is endemic BCG vaccination confers consistent efficacy against disseminated forms of TB in childhood, such as TB meningitis and miliary TB, however, its protective efficacy against adult-type pulmonary TB varies $[1,2]$. Factors that have been implicated include BCG strain, route of administration, geographical location, exposure to environmental mycobacteria and helminth infection [3]. There is increasing evidence, especially in regions affected by a high infectious disease burden, that apart from protecting against TB, BCG may reduce infant mortality from unrelated infections. Here we review the evidence for this phenomenon, discuss potential mechanisms and outline the possible implications for future vaccine candidates.

\section{All-cause infant mortality reduction}

Observational studies reported that BCG, alone or in combination with other vaccines, might decrease the all-cause mortality risk up to $30-50 \%$ for up to 2 years of age in West Africa [4-6], extending to up to 5 years of age in Uganda [7]. More specifically, it was shown that immunizing low-birth-weight infants with BCG at birth could significantly improve their survival for the first month of life because of decreased infection risk [8]. Similar findings were reported in India, where mortality rates were lower in BCG-vaccinated infants for up to 6 months of age, compared with the unvaccinated infant group [9]. Studies in Malawi and Guinea-Bissau also found a trend for reduced mortality among infants vaccinated with BCG $[10,11]$. Although the extent of BCG-dependent nonspecific reduction in infant mortality is difficult to evaluate, with the efficacy estimates reaching $6-72 \%$ in clinical trials 
or $2-95 \%$ in observational studies $[12,13]$, this evidence suggests that BCG may exert a beneficial, heterologous influence on infant survival, reducing mortality unrelated to TB.

\section{Impact on acquisition of infectious diseases}

BCG may also reduce the acquisition of nonmycobacterial infections. In Uganda, BCG-vaccinated HIV-positive adults had lower risk of intestinal nematode infection than unvaccinated individuals [14]. BCG vaccination also decreased risk of heterologous infections in infants. In Guinea-Bissau, BCG-immunized infants had lower rates of neonatal sepsis and respiratory infection [8]. Similarly, hospitalization rate due to nontubercular respiratory infections and sepsis in Spain was lower among the BCG-vaccinated children [15]. A recent analysis of infant immunization with BCG in 33 countries suggested BCG vaccination may reduce acute lower respiratory infection incidence by $17-37 \%$ [16]. In contrast, a randomized trial in Denmark found no association between neonatal BCG vaccination and infection incidence [17]. The reasons for the discrepancies are not clear, although it has been suggested that benefits of infant BCG immunization in low-income settings may be partially accounted by lowered undiagnosed mycobacterial infection rate [18]. Such infections would be less likely in a setting with low infectious disease burden. Together, these studies imply that nonspecific BCG effects may be particularly beneficial in countries with high infectious disease load, reducing both the all-cause mortality and the disease incidence.

\section{Factors potentially contributing to the heterologous effects of BCG vaccination BCG timing \& interaction with other vaccines}

Some studies suggested that diphtheria-tetanus-pertussis (DTP) vaccine might affect the impact of BCG on childhood mortality $[4,9]$; implicating that other vaccines may modulate the nonspecific effects of BCG immunization (Table 1). In contrast, a study in Burkina Faso found that risk of mortality before 2 years of age was reduced to a similar extent in infants vaccinated with BCG-only or both BCG and DTP [5]. Vaccination timing and sequence were suggested as potentially important to the nonspecific effects of vaccines, as studies in Senegal and Philippines found that immunizing infants with DTP at or following BCG administration was associated with enhanced survival [6,19-21]. Proposals were made that BCG following DTP might reduce all-cause infant mortality even further [22-24]. The WHO Strategic Advisory Group of Experts addressed the controversy of nonspecific BCG and DTP interactions in 2014 and concluded that the evidence for such effects was insufficient [13].

\section{Infant age \& time post-BCG vaccination}

The extent to which heterologous effects of BCG vaccination are apparent may depend on age of the infant. BCG-dependent reduction in overall infant mortality may be the most evident in the first few months of life, before the nonspecific infant protection becomes influenced by the administration of subsequent vaccines $[4,8]$; however, in other studies heterologous effects are still apparent for up to 24 months of age [5,6]. Some studies reported BCGassociated reduction in overall mortality of children aged up to 5 years $[7,25]$ or decrease in hospitalization rates due to nonmycobacterial infections in children up to 14 years of age [15]. This may be a consequence of improved early childhood survival as BCG-related reduction in hospitalization due to sepsis was the most significant in children aged 1-4 years, diminishing in older children [15]. This implies that the heterologous BCG effects manifest soon after immunization, but wane over time and may be the most apparent for neonates vaccinated at birth. Another possibility is that as infants grow older, they become exposed to pathogens more frequently, with the resulting development of the classical immunity against infectious diseases eventually overcoming the heterologous beneficial effects of BCG.

\section{Sex-differential effects of BCG vaccination}

Some studies indicate that BCG-dependent nonspecific infant mortality reduction may be influenced by male or female sex, females possibly benefitting from heterologous BCG effects more than males [9,26,27]. A review of female-male twin pair datasets from Guinea-Bissau and Senegal found that the survival benefit of BCG vaccination in females was variable, possibly due to low death rates observed among the vaccinated twin pairs [28]. No BCGassociated survival benefit in female infants was observed over the first 8 months of life in an Indian infant cohort [29], although this could be attributable to excess background female neonatal mortality in this region. No sex-related differences in heterologous BCG protection were observed in Burkina Faso [5]. SAGE addressed this issue in 2014; however, no evidence for differences in BCG-immunized female or male heterologous mortality reduction was found [13]. Of interest, some studies indicated that BCG-vaccinated females may produce higher 
Table 1. Nonspecific infant mortality reduction by BCG and interaction with diphtheria-tetanus-pertussis.

\begin{tabular}{|c|c|c|c|c|c|c|c|}
\hline Study & Study type & Vaccine schedule $^{\dagger}$ & $\begin{array}{l}\text { BCG-vaccinated vs } \\
\text { unvaccinated infants }\end{array}$ & $\begin{array}{l}\text { DTP-vaccinated vs } \\
\text { unvaccinated infants }\end{array}$ & BCG vs BCG \& DTP & $\begin{array}{l}\text { Observed age } \\
\text { group }\end{array}$ & Ref. \\
\hline $\begin{array}{l}\text { Guinea- } \\
\text { Bissau }\end{array}$ & Cohort & $\begin{array}{l}\text { BCG \& OPV at birth; } \\
\text { DTP at } 6,10 \& \\
14 \text { weeks; } \\
\text { MV at } 9 \text { months }\end{array}$ & $\begin{array}{l}\text { Mortality rate: } \\
\text { At } 6-12 \text { months of age } \\
3.9 \% \text { among } \\
\text { BCG-vaccinated } \\
4.9 \% \text { among BCG not } \\
\text { vaccinated }\end{array}$ & $\begin{array}{l}\text { Mortality rate: } \\
\text { At } 7.5-12 \text { months of } \\
\text { age } \\
4.8 \% \text { among } \\
\text { DTP-vaccinated } \\
4.0 \% \text { among DTP not } \\
\text { vaccinated }\end{array}$ & $\begin{array}{l}\text { Mortality rate: } \\
\text { At } 7.5-9 \text { months of age } \\
3.9 \% \text { among BCG \& } \\
\text { DTP; } \\
2.5 \% \text { among BCG only } \\
\text { At } 10-12 \text { months of } \\
\text { age } \\
5.6 \% \text { among BCG \& } \\
\text { DTP; } \\
4.1 \% \text { among BCG only }\end{array}$ & $\begin{array}{l}\text { Up to } 5 \text { years of } \\
\text { age }\end{array}$ & {$[4,5]$} \\
\hline Burkina Faso & Cohort & $\begin{array}{l}\text { BCG at birth; } \\
\text { DTP at } 6,10 \text { \& } \\
14 \text { weeks } \ddagger\end{array}$ & $\begin{array}{l}\text { Mortality before } 2 \\
\text { years of age risk ratio } \$ \text { : } \\
0.37\end{array}$ & $\begin{array}{l}\text { Mortality before } 2 \\
\text { years of age risk ratio }{ }^{\S} \text { : } \\
0.23\end{array}$ & $\begin{array}{l}\text { Mortality before } 2 \\
\text { years of age risk ratio } \$ \text { : } \\
\text { BCG \& DTP vs } \\
\text { unvaccinated } \\
0.34\end{array}$ & $\begin{array}{l}\text { Up to } 2 \text { years of } \\
\text { age }\end{array}$ & \\
\hline Senegal & Cohort & $\begin{array}{l}\text { DTP-IPV at } 2,4 \& \\
6 \text { months } \mathbb{I} ; \\
\text { BCG administered with } \\
\text { the first DTP-IPV; } \\
\text { MV at } 9-10 \text { months }\end{array}$ & Not analyzed & & $\begin{array}{l}\text { BCG \& DTP vs } \\
\text { unvaccinated mortality } \\
\text { before } 2 \text { years of age } \\
\text { ratio: } \\
\text { cohort } 1 \mathbb{I}: 0.70 \text { cohort } \\
2 \mathbb{I}: 0.59(0.46-0.74)\end{array}$ & $\begin{array}{l}\text { Up to } 2 \text { years of } \\
\text { age }\end{array}$ & [6] \\
\hline Senegal & Cohort & $\begin{array}{l}\text { Recommended } \\
\text { schedule: } \\
\text { BCG at birth; } \\
\text { DTP \& OPV at } 6,10 \text { \& } \\
14 \text { weeks; } \\
\text { MV at } 9 \text { months } \\
\text { BCG first: } \\
\text { BCG vaccinated, DTP1 } \\
\text { not yet received; } \\
\text { DTP1, DTP2 or DTP3 } \\
\text { following BCG } \\
\text { BCG \& DTP first: } \\
\text { DTP2 or DTP3 } \\
\text { following BCG \& DTP } \\
\text { simultaneously } \\
\text { DTP first: } \\
\text { BCG following DTP1, } \\
\text { DTP2 or DTP3 }\end{array}$ & $\begin{array}{l}\text { Mortality rate ratio: } \\
0.98-\text { BCG-vaccinated, } \\
\text { DTP1 not yet received }\end{array}$ & $\begin{array}{l}\text { Mortality rate ratio: } \\
1.33 \text { - DTP1, no BCG } \\
1.41 \text { - DTP2, no BCG } \\
0.63 \text { - DTP3, no BCG }\end{array}$ & $\begin{array}{l}\text { Mortality rate ratio: } \\
0.98 \text { - BCG-vaccinated, } \\
\text { DTP1 not yet received } \\
0.96 \text { - BCG first } \\
0.69 \text { - BCG \& DTP first } \\
1.10 \text { - DTP first }\end{array}$ & $\begin{array}{l}\text { Up to } 24 \text { months } \\
\text { of age }\end{array}$ & [21] \\
\hline $\begin{array}{l}\text { Guinea- } \\
\text { Bissau }\end{array}$ & $\begin{array}{l}\text { Randomized } \\
\text { trial }\end{array}$ & $\begin{array}{l}\text { BCG \& OPV at birth; } \\
\text { DTP \& OPV at } 6,10 \text { \& } \\
14 \text { weeks; } \\
\text { MV at } 9 \text { months; } \\
\text { DTP \& OPV booster at } \\
18 \text { months; } \\
\text { BCG revaccination at } \\
19 \text { months }\end{array}$ & \multicolumn{2}{|c|}{$\begin{array}{l}\text { BCG revaccination vs no revaccination HR: } \\
1.20 \text { - the whole study period }\end{array}$} & $\begin{array}{l}\text { BCG revaccination vs } \\
\text { no revaccination HR: } \\
0.36 \text { - DTP booster } \\
\text { given prior to the trial } \\
1.78 \text { - no DTP booster } \\
\text { prior to the trial }\end{array}$ & $\begin{array}{l}\text { Up to } 5 \text { years of } \\
\text { age }\end{array}$ & [23] \\
\hline India & Cohort & $\begin{array}{l}\text { BCG at } 0-12 \text { months; } \\
\text { OPV at birth, } 6,10 \& \\
14 ; \\
\text { DTP at } 6,10 \& 14 \text { weeks }\end{array}$ & $\begin{array}{l}\mathrm{HR}^{\#} \text { : } \\
0.62 \text { - for } \\
\text { BCG-vaccinated vs no } \\
\text { BCG } \\
0.44 \text { - BCG only, no DTP } \\
0.72 \text { - BCG \& DTP }\end{array}$ & $\begin{array}{l}\mathrm{HR}^{\#}: \\
0.70 \text { - DTP prior to BCG } \\
0.44 \text { - DTP only }\end{array}$ & & $\begin{array}{l}\text { Up to } 6 \text { months } \\
\text { of age }\end{array}$ & [9] \\
\hline Philippines & Cohort & $\begin{array}{l}\text { BCG at } 0-11 \text { weeks; } \\
\text { DTP \& polio vaccine at } \\
6,10 \& 14 \text { weeks }{ }^{\dagger \dagger} \\
\text { MV at } 9 \text { months }\end{array}$ & \multicolumn{2}{|c|}{ BCG-vaccinated infants only. } & $\begin{array}{l}H R^{\ddagger \ddagger}: \\
0.18 \text { - females, no DTP } \\
0.27 \text { - DTP-vaccinated } \\
\text { females } \\
0.32 \text { - DTP-vaccinated } \\
\text { males }\end{array}$ & $\begin{array}{l}\text { Up to } 30 \text { months } \\
\text { of age }\end{array}$ & [19] \\
\hline
\end{tabular}

†Vaccination timings correspond to infant age at the time of vaccination.

¥Infants were considered unvaccinated until the age of immunization with a specified vaccine.

$\S$ Adjusted for the area, dispensary in a village, use of health services, diarrhea in the first year of life and birth season.

I Cohort 1 vaccinated as indicated in the Vaccination Schedule section. Cohort 2 received OPV instead of IPV.

\#Assumed HR for unvaccinated infants equals 1.

††Type of polio vaccine was not specified.

$¥ \ddagger$ Assumed HR for infant males not vaccinated with DTP equals 1 . The cited HR rates exclude two deaths of infants with an unknown DTP vaccination status.

$\S \S$ Mortality rate ratio adjusted for most recent weight and controlled for age.

DTP1, 2 or 3: First, second or third dose of diphtheria-tetanus-pertussis vaccine; HR: Hazard ratio; IPV: Inactivated polio vaccine; MV: Measles vaccine; OPV: Oral polio vaccine. 


\begin{tabular}{|c|c|c|c|c|c|c|c|}
\hline Study & Study type & Vaccine schedule ${ }^{\dagger}$ & $\begin{array}{l}\text { BCG-vaccinated vs } \\
\text { unvaccinated infants }\end{array}$ & $\begin{array}{l}\text { DTP-vaccinated vs } \\
\text { unvaccinated infants }\end{array}$ & BCG vs BCG \& DTP & $\begin{array}{l}\text { Observed age } \\
\text { group }\end{array}$ & Ref. \\
\hline India & Cohort & $\begin{array}{l}\text { Recommended } \\
\text { schedule: } \\
\text { BCG at birth; } \\
\text { DTP \& OPV at 2, } 3 \text { \& } \\
4 \text { months; } \\
\text { MV at } 9 \text { months; } \\
\text { DTP \& OPV booster at } \\
18 \text { months } \\
\text { Altered sequence of } \\
\text { BCG and DTP } \\
\text { vaccination: } \\
\text { BCG \& DTP } \\
\text { simultaneously } \\
\text { BCG following DTP }\end{array}$ & $\begin{array}{l}\text { Mortality rate to } 1 \text { year } \\
\text { of age: } \\
2.2 \% \text { in BCG only } \\
\text { group } \\
3.6 \% \text { in the } \\
\text { unvaccinated group }\end{array}$ & $\begin{array}{l}\text { Mortality rate to } 1 \text { year } \\
\text { of age: } \\
2.4 \% \text { in DTP only group } \\
3.6 \% \text { in the } \\
\text { unvaccinated group }\end{array}$ & $\begin{array}{l}\text { Mortality rate ratio in } \\
\text { the first 9-12 months } \\
\text { prior to receiving } \\
\text { MV } \$ 8 \text { : } \\
0.11 \text { - BCG \& DTP } \\
\text { simultaneously and the } \\
\text { last in the sequence vs } \\
\text { DTP following BCG } \\
0.14 \text { - BCG \& DTP } \\
\text { simultaneously and the } \\
\text { last in the sequence vs } \\
\text { DTP only } \\
0.13-\text { BCG \& DTP } \\
\text { simultaneously and the } \\
\text { last in the sequence vs } \\
\text { DTP as the last vaccine } \\
\text { in the sequence } \\
0.27 \text { - BCG alone or } \\
\text { BCG \& DTP } \\
\text { simultaneously and the } \\
\text { last in the sequence vs } \\
\text { DTP as the last vaccine } \\
\text { in the sequence }\end{array}$ & $\begin{array}{l}\text { Up to } 5 \text { years of } \\
\text { age }\end{array}$ & [24] \\
\hline
\end{tabular}

†Vaccination timings correspond to infant age at the time of vaccination.

$¥$ Infants were considered unvaccinated until the age of immunization with a specified vaccine.

$\S$ Adjusted for the area, dispensary in a village, use of health services, diarrhea in the first year of life and birth season.

I Cohort 1 vaccinated as indicated in the Vaccination Schedule section. Cohort 2 received OPV instead of IPV.

\#Assumed HR for unvaccinated infants equals 1.

††Type of polio vaccine was not specified.

¥Assumed HR for infant males not vaccinated with DTP equals 1 . The cited HR rates exclude two deaths of infants with an unknown DTP vaccination status.

$\S \S$ Mortality rate ratio adjusted for most recent weight and controlled for age.

DTP1, 2 or 3: First, second or third dose of diphtheria-tetanus-pertussis vaccine; HR: Hazard ratio; IPV: Inactivated polio vaccine; MV: Measles vaccine; OPV: Oral polio vaccine.

levels of inflammatory cytokines in response to nonmycobacterial stimuli than males at 4 weeks [30] or 1 and 12 weeks [31] postvaccination. Therefore, immunological mechanisms of heterologous effects of BCG vaccination may be sex-dependent; however, their contribution to heterologous infant mortality is not clear.

\section{Mechanisms implicated in heterologous BCG-vaccinated infant protection BCG-inducible trained innate immunity}

A tempting candidate to explain the heterologous effects of BCG is the phenomenon of innate immune response training [32-34]. Originally identified in NK cells, innate memory or training enables the innate cells to respond more rapidly and strongly to antigens unrelated to the original stimulus and was shown to be BCG-inducible in monocytes. Pre-exposure of murine macrophages to BCG was demonstrated to increase their ability to cope with Candida albicans infection both in vitro and in vivo [35]. In humans, monocytes of BCG-vaccinated adults had increased expression of surface markers of activation and produced more IL-1 $\beta$, IL- 6 , IFN- $\gamma$ and TNF- $\alpha$ in response to Staphylococcus aureus or $C$. albicans for up to 3 months postvaccination compared with monocytes isolated before vaccination from the same adults (Figure 1) [36,37]. Interestingly, while surface receptor expression on monocytes from BCG-vaccinated adults was upregulated for up to a year, IL-1 $\beta$ and TNF- $\alpha$ production upon nonmycobacterial antigen stimulation diminished by this time [38]. This suggests that the most potent effects of heterologous BCG-trained immunity manifest over the first few months post-BCG vaccination. Apart from inducing functional, lasting monocyte changes, BCG enhanced the vaccinated adult NK cell IL-1 $\beta$ and IL-6 production in response to $C$. albicans and $S$. aureus for up to 3 months, also, improving T- and B-cell deficient mice, infected with $C$. albicans, survival [36,39]. This is consistent with the observations that BCG-associated reduction in all-cause infant mortality is the most significant during the first few months of life [4-5,8], implying that BCG-trained monocyte and NK cell immunity may contribute to broad infant protection from infectious diseases when they are the most susceptible. 


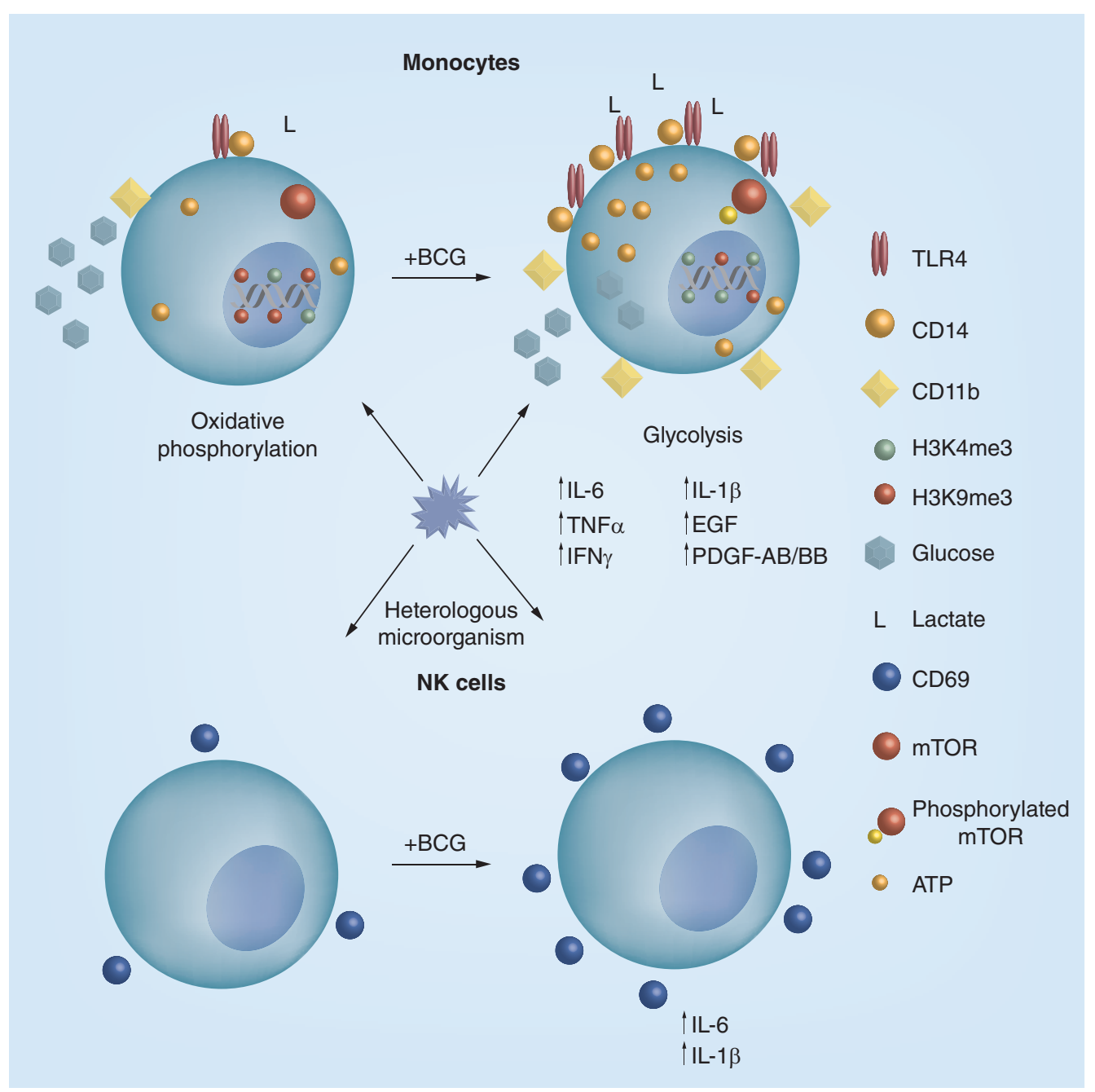

Figure 1. BCG training-induced phenotype changes in monocytes and NK cells. BCG training of human monocytes in vitro or by vaccination increases their surface marker expression and cytokine production in response to heterologous antigen stimulation $[36,40]$. In monocytes, these changes are regulated by metabolic shift from oxidative phosphorylation to glycolysis and histone modifications [41], with increased frequency of permissive $\mathrm{H} 3 \mathrm{~K} 4 \mathrm{me} 3$ and reduced presence of inhibitory $\mathrm{H} 3 \mathrm{~K} 9 \mathrm{me} 3$ at the promoters of cytokine, receptor and metabolic pathway component encoding genes $[36,37,41-43]$. The left side of the diagram depicts model innate immune cells prior to the BCG training and the right side - post-training. Enhanced cytokine production post-training is indicated by arrows. Heterologous microorganism - secondary, nonmycobacterial infectious agent.

$+\mathrm{BCG}-$ in vitro or in vivo cell training with BCG.

TLR4: Toll-like receptor 4; H3K4me3: Trimethylation of lysine at position 4 on histone 3; H3K9me3: Trimethylation of lysine at position 9 on histone 3.

\section{Metabolic changes induced by innate immune training}

Functional monocyte changes induced by BCG training have been associated with a metabolic shift from oxidative phosphorylation to aerobic glycolysis (Figure 1). First demonstrated in monocyte in vitro training with $\beta$-glucan phosphorylation [44]. Similar changes were observed in BCG-dependent monocyte training [41]. Peripheral blood mononuclear cells upon heterologous stimulation than cells obtained prior to the vaccination [41]. This correlates with the previous findings that monocytes obtained from BCG-immunized donors at these time points produce higher cytokine levels than monocytes isolated before the immunization [36,37,42]. Of note, inhibition of mTOR and glycolysis pathways diminished ex vivo BCG-trained human monocyte production of lactate, TNF and IL-6 upon lipopolysaccharide (LPS) challenge, supporting the role for glycolysis in the innate immune training [41]. Importantly, polymorphisms of HK2 and PFKP were associated with the ability of monocytes to be trained and produce cytokines in response to LPS [41]. This implies BCG-inducible training may be ineffective in some 


\begin{tabular}{|c|c|c|c|c|c|c|c|}
\hline Gene & Product & Function & $\begin{array}{l}\text { Histone } \\
\text { modification }\end{array}$ & $\begin{array}{l}\text { Impact on gene } \\
\text { expression }\end{array}$ & Cell type & Model & Ref. \\
\hline \multirow[t]{5}{*}{$\begin{array}{l}\text { TNF- } \alpha \\
\text { IL-6 }\end{array}$} & $\begin{array}{l}\text { TNF- } \alpha \\
\text { IL-6 }\end{array}$ & Immune responses & $\uparrow \mathrm{H} 3 \mathrm{~K} 4 \mathrm{me} 3$ & Permissive & Monocytes & $\begin{array}{l}\text { In vivo/BCG } \\
\text { vaccination }\end{array}$ & [36] \\
\hline & & & & & & $\begin{array}{l}\text { In vitro } / \gamma \mathrm{BCG} \\
\text { training }\end{array}$ & [42] \\
\hline & & & & & & $\begin{array}{l}\text { In vitro/BCG } \\
\text { training }\end{array}$ & [37] \\
\hline & & & $\begin{array}{l}\uparrow \mathrm{H} 3 \mathrm{~K} 4 \mathrm{me} 3 \\
\downarrow \mathrm{H} 3 \mathrm{~K} 9 \mathrm{me} 3\end{array}$ & $\begin{array}{l}\text { Permissive } \\
\text { Inhibitory }\end{array}$ & Monocytes & $\begin{array}{l}\text { In vitro/BCG } \\
\text { training }\end{array}$ & [41] \\
\hline & & & $\downarrow \mathrm{H} 3 \mathrm{~K} 9 \mathrm{me} 3$ & Inhibitory & $\begin{array}{l}\text { Monocytes/ } \\
\text { macrophages }\end{array}$ & $\begin{array}{l}\text { In vitro/BCG } \\
\text { training }\end{array}$ & [43] \\
\hline $\begin{array}{l}\text { mTOR } \\
\text { HK2 } \\
\text { PFKP }\end{array}$ & $\begin{array}{l}\text { mTOR } \\
\text { Hexokinase } 2 \\
\text { Platelet phospho- } \\
\text { fructokinase }\end{array}$ & Glycolysis & $\begin{array}{l}\uparrow \mathrm{H} 3 \mathrm{~K} 4 \mathrm{me} 3 \\
\downarrow \mathrm{H} 3 \mathrm{~K} 9 \mathrm{me3}\end{array}$ & $\begin{array}{l}\text { Permissive } \\
\text { Inhibitory }\end{array}$ & Monocytes & $\begin{array}{l}\text { In vitro/BCG } \\
\text { training }\end{array}$ & [41] \\
\hline $\begin{array}{l}\text { GLS } \\
\text { GLUD }\end{array}$ & $\begin{array}{l}\text { Glutaminase } \\
\text { Glutamate } \\
\text { dehydrogenase }\end{array}$ & Glutaminolysis & $\begin{array}{l}\uparrow \mathrm{H} 3 \mathrm{~K} 4 \mathrm{me} 3 \\
\downarrow \mathrm{H} 3 \mathrm{~K} 9 \mathrm{me} 3\end{array}$ & $\begin{array}{l}\text { Permissive } \\
\text { Inhibitory }\end{array}$ & Monocytes & $\begin{array}{l}\text { In vitro/BCG } \\
\text { training }\end{array}$ & [41] \\
\hline
\end{tabular}

individuals with metabolic component polymorphisms. Other pathways may be involved in innate immune training. Monocytes trained in vitro with BCG or oxidized low-density lipoprotein (oxLDL) were shown to increase reactive oxygen species production upon stimulation with zymosan, a yeast-derived ligand of TLR2 [45]. BCG enhanced IL- 6 and TNF- $\alpha$ production in histone 3 lysine 4 trimethylation dependent manner, this effect is also demonstrated for oxLDL [36,42]. Interestingly, oxLDL stimulated monocyte scavenger receptor and CD36 expression and differentiation to foam cells [46]. Mycobacteria can interfere with the host's lipid metabolism and drive foam cell formation [47], suggesting that BCG may also exploit lipid metabolism to induce monocyte training.

\section{Epigenetic regulation of innate immune training}

Epigenetic mechanisms, largely, histone modifications, regulate monocyte training (Figure $1 \&$ Table 2). For example, enhanced surface activation marker and inflammatory cytokine expression upon nonmycobacterial stimulation of monocytes from BCG-vaccinated adults was associated with intracellular nucleotide sensor NOD2 dependent $\mathrm{H} 3 \mathrm{~K} 4$ trimethylation of promoters of genes encoding these monocyte markers and cytokines [36,42]. In addition, active promoters of $\beta$-glucan-trained monocytes contained higher levels of permissive histone modifications, such as $\mathrm{H} 3 \mathrm{~K} 4 \mathrm{me} 3$ and histone 3 lysine 27 acetylation than promoters in untrained monocytes [44]. The accumulation of these epigenetic markers of promoter activation at the glycolysis and mTOR pathway component genes implied cellular metabolism in innate immune training [44]. BCG-inducible monocyte training enriched the activating H3K4me3 modification at mTOR, glycolytic enzyme, tnf and il-6 gene promoters [41]. However, the regulatory patterns of training-related histone modifications seem to be complex as mTOR or glutamine pathway inhibition cancelled H3K4me3 accumulation at the cytokine promoters [41]. Importantly, not only the permissive, but also inhibitory histone modifications, such as histone 3 lysine 9 trimethylation regulate glycolysis and mTOR pathway component or inflammatory cytokine expression in BCG-trained cells [41,43]. BCG training was shown to suppress $\mathrm{H} 3 \mathrm{~K} 9 \mathrm{me} 3$ mark while inhibition of glutamine or mTOR pathways enhanced the accumulation of this mark at the inflammatory cytokine promoters [41]. This suggests that enzymes managing histone modification patterns may respond to intracellular metabolite changes, coordinating cytokine or other gene expression accordingly.

\section{Infant BCG immunization \& innate immune training}

The evidence on whether BCG induces trained innate immunity in infants and if it contributes to their protection from nonmycobacterial pathogens is somewhat controversial. Although adult BCG vaccination or in vitro training models suggest that BCG primes monocytes to increase surface activation markers and type 1 cytokine production in response to heterologous antigen stimulation [36,37,42], infant immune responses to BCG seem more difficult to define. Differently from adults, no differences in monocyte surface activation marker expression were observed upon whole blood stimulation with heterologous stimuli in the BCG-immunized infant group versus unvaccinated 
controls [40]. However, Pam3CSK4 stimulation upregulated NK cell activation marker CD69 in the vaccinated infant samples, implying that NK cells may mediate heterologous BCG effects in infants, similar to the NK cells of the BCG-vaccinated adults [39]. Likewise, in agreement with the adult studies, whole blood samples from BCG-immunized low-birth-weight infants produced more TNF- $\alpha$, IFN- $\gamma$, IL-1 $1 \beta$ and IL- 6 upon Pam3CSK4 stimulation compared with the unvaccinated infants (Table 3) [30]. Yet, different cytokine profile was identified in BCG-vaccinated UK infant whole blood cultures, with higher levels of EGF, IL-6, PDGF-AB/BB in response to Pam3CSK4, C. albicans and S. aureus challenge compared with the control group [40]. Previous studies explored narrower cytokine profiles $[30,36,37]$, so it is not clear if discrepancies reflect differences in the adult and the infant immune systems or diverse study design.

Other studies did not confirm the association between infant BCG vaccination status and heterologous immune responses. In contrast to previous findings, no TNF- $\alpha$ production changes at 1 and 12 weeks postimmunization were found in BCG-vaccinated Gambian infants upon their PBMC stimulation with heterologous microorganisms (Table 3) [31]. In addition, no significant changes in cytokine responses to nonspecific stimuli were observed at 3 and 13 months postrandomization in whole blood samples obtained from the BCG-vaccinated infants compared with the controls in Denmark [51]. The reasons for the discrepancies among the findings from different studies are not clear, although potentially low immunogenicity of BCG used in some studies was suggested as a possible cause $[31,51,52]$. In Uganda, maternal BCG scar was associated with stronger inflammatory responses in infants upon whole blood culture stimulation with TLR agonists [53], suggesting that maternal BCG status could affect infant responses. Differences in the vaccination schedules, study design or infant populations may also contribute to diverse outcomes in such studies.

\section{BCG \& other innate immune responses}

Other mechanisms may contribute to the heterologous BCG effects. BCG-dependent immune training was shown to elevate levels of IL-6, TNF- $\alpha$ and IL-1 $\beta$ in BCG-vaccinated adults and infants 2 weeks to several months postvaccination in response to heterologous stimuli $[30,36,37,40,42]$. These cytokines can mediate the acute phase responses, suggesting that BCG-primed immune system might exploit plasma iron regulation upon encounter with infectious microorganisms. However, a study of Gambian neonates found no association between the vaccination status and plasma iron, hemoglobin, hepcidin, ferritin or IL-6 levels in the unvaccinated controls and neonates vaccinated with oral polio vaccine, HBV and BCG at birth or given BCG at 5 days of age [54]. The authors argued that early responses were measured, potentially missing out BCG-dependent nonspecific effects and that the observed neonate plasma levels of IL-6, hepcidin and ferritin were elevated irrespective of immunization status as a consequence of the birth process, potentially masking the nonspecific effects of BCG [54]. Further studies exploring a possible relationship between the acute phase responses in infants and nonspecific effects of BCG would be of interest.

\section{BCG-enhanced heterologous T-cell responses}

BCG may steer the immune system toward Th1-type proinflammatory cytokine production, activating monocytes and alveolar macrophages, so mediating classical antimycobacterial effects. However, this effect may extend beyond mycobacterial specificity. In mice, BCG immunization enhanced protection from vaccinia virus via increased $\mathrm{CD}^{+}{ }^{+}$T-cell IFN- $\gamma$ production [55]. Studies on human infant responses to BCG show similar effects (Table 3). BCG-Denmark improved IFN- $\gamma$ and IL-10 responses to tetanus toxoid at 12 months of age in a Ugandan infant cohort [49]. In Philippines, infants, given BCG at birth, had higher frequencies of tetanus toxoid specific PBMCs producing IFN- $\gamma$ and $\mathrm{CD}_{4}^{+}$memory T cells secreting IFN- $\gamma$ and TNF- $\alpha$ upon phytohemagglutinin stimulation [52]. In Guinea-Bissau, BCG-vaccinated infants produced more IFN- $\gamma$ than unvaccinated controls upon whole blood stimulation with phorbol myristate acetate [30]. PBMCs from Gambian infants vaccinated with BCG at birth produced higher levels of IFN- $\gamma$, IL-5 and IL-13 in response to hepatitis B surface antigen, and their lymphocytes were more proliferative compared with the cells from control infants [48]. Increased IFN- $\gamma$-producing $\mathrm{CD}^{+}{ }^{+}$-cell frequency upon $C$. albicans stimulation at 1 week post-BCG immunization was observed in another Gambian infant cohort, although this effect subsided by 12 weeks postvaccination [31]. This study also reported reduced IL-10 production in response to LPS and increased IFN- $\gamma /$ IL-10 ratio upon $S$. pneumoniae stimulation in BCG-vaccinated females at 12 weeks postimmunization [31]. Together, these studies suggest that BCG vaccine may enhance maturation of Th1 cells with diverse specificities, improving responses to a broad range of microbial or childhood vaccine antigens. As infant immune responses shift from Th17-like toward Th1-type in the first year 


\begin{tabular}{|c|c|c|c|c|c|c|c|c|}
\hline \multirow[t]{2}{*}{ Study } & \multirow[t]{2}{*}{ Vaccine schedule $^{\dagger}$} & \multirow[t]{2}{*}{ Assay } & \multirow{2}{*}{$\begin{array}{l}\text { Age at } \\
\text { observation }\end{array}$} & \multirow{2}{*}{$\begin{array}{l}\text { Secondary } \\
\text { stimulus }\end{array}$} & \multicolumn{4}{|c|}{ BCG vs control } \\
\hline & & & & & Cytokine production & $\begin{array}{l}\text { Surface } \\
\text { marker } \\
\text { expression }\end{array}$ & Proliferation & Ref. \\
\hline \multirow[t]{2}{*}{ The Gambia } & $\begin{array}{l}\text { BCG-Pasteur at birth } \\
\text { or } \\
\text { BCG at } 2 \text { months } \\
\text { HBV at birth, } 2 \& \\
4 \text { months; } \\
\text { OPV at birth, } 1,2 \& \\
3 \text { months; } \\
\text { DTP at } 2,3 \& 4 \text { months } \\
\text { control - BCG at } \\
4.5 \text { months }\end{array}$ & PBMCs & $\begin{array}{l}\text { At birth, } 2 \text { \& } \\
4 \text { months }\end{array}$ & $\mathrm{HBsAg}$ & $\begin{array}{l}\uparrow I F N-\gamma, \text { IL- } 5 \text { and IL- } 13 \\
\text { at } 2 \text { and } 4.5 \text { months of } \\
\text { age in infants given } \\
\text { BCG at birth } \\
\text { 个IL- } 5 \text { and IL-13 at } \\
4.5 \text { months of age in } \\
\text { infants given BCG at } \\
2 \text { months }\end{array}$ & & $\begin{array}{l}\uparrow \text { Lymphocyte } \\
\text { proliferation at } 2 \text { and } \\
4.5 \text { months in infants } \\
\text { given BCG at birth } \\
\text { 个lymphocyte } \\
\text { proliferation at } \\
4.5 \text { months in infants } \\
\text { given BCG at } 2 \text { months }\end{array}$ & [48] \\
\hline & & & & TT & 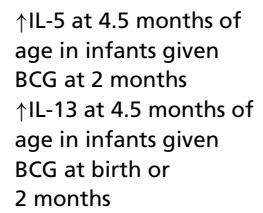 & & $\begin{array}{l}\text { No lymphocyte } \\
\text { proliferation changes }\end{array}$ & \\
\hline \multirow[t]{2}{*}{ Uganda } & $\begin{array}{l}\text { BCG-Bulgaria, } \\
\text { BCG-Denmark or } \\
\text { BCG-Russia at birth; } \\
\text { OPV at birth, } 6,10 \text { \& } \\
14 \text { weeks; } \\
\text { DTP, Hib and HBV } \\
\text { MV at } 9 \text { months }\end{array}$ & Whole blood & 12 months & $\pi$ & 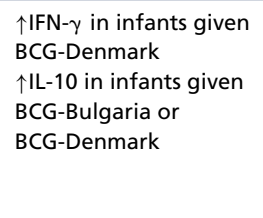 & & & [49] \\
\hline & & & & PHA & $\begin{array}{l}\text { 个IFN- } \gamma \text {, IL-10, IL-13 in } \\
\text { infants given } \\
\text { BCG-Denmark }\end{array}$ & & & \\
\hline \multirow[t]{2}{*}{ South Africa } & $\begin{array}{l}\text { BCG-Denmark at birth } \\
\text { control - BCG at } \\
8 \text { weeks }\end{array}$ & Whole blood & $8 \& 14$ weeks & SEB & n.s. & & $\begin{array}{l}\uparrow C D 4^{+} T \text {-cell } \\
\text { proliferation at } \\
14 \text { weeks }\end{array}$ & [50] \\
\hline & & & & $\mathrm{BP}$ & $\begin{array}{l}\uparrow \mathrm{IL}-2+\mathrm{CD}^{+} \mathrm{T} \text { cells at } \\
8 \text { weeks } \\
\uparrow \mathrm{IL}-13+\mathrm{CD} 4^{+} \text {and } \\
\mathrm{CD} 8^{+} \mathrm{T} \text { cells at } \\
14 \text { weeks }\end{array}$ & & & \\
\hline \multirow[t]{2}{*}{$\begin{array}{l}\text { Guinea- } \\
\text { Bissau }\end{array}$} & $\begin{array}{l}\text { OPV at birth; } \\
\text { BCG-Denmark at birth; } \\
\text { Penta at } 6 \text { weeks } \\
\text { control - BCG at } \\
6 \text { weeks }\end{array}$ & Whole blood & 4 weeks & Pam3CSK4 & $\begin{array}{l}\uparrow I L-1 \beta, \text { IL-6, TNF- } \alpha \text {, } \\
\text { IFN- } \gamma\end{array}$ & & & [30] \\
\hline & & & & $\begin{array}{l}\text { PMA \& } \\
\text { ionomycin }\end{array}$ & $\uparrow I L-6$, IFN- $\gamma$ & & & \\
\hline \multirow[t]{4}{*}{ The Gambia } & $\begin{array}{l}\text { OPV \& HBV at birth; } \\
\text { BCG-Russia at } 6 \text { weeks; } \\
\text { Penta, PCV-13 \& OPV at } \\
8,12 \& 16 \text { weeks; } \\
\text { control - BCG at } \\
18 \text { weeks }\end{array}$ & PBMC & $\begin{array}{l}6,7 \& \\
18 \text { weeks }\end{array}$ & LPS & $\begin{array}{l}\downarrow \mathrm{IL}-10 \text { in females at } \\
18 \text { weeks }{ }^{\ddagger}\end{array}$ & & & [31] \\
\hline & & & & $\begin{array}{l}\text { PMA \& } \\
\text { ionomycin }\end{array}$ & $\begin{array}{l}\downarrow \text { IFN- } \gamma \text { in females at } \\
18 \text { weeks }{ }^{\ddagger}\end{array}$ & & & \\
\hline & & & & Candida albicans & $\begin{array}{l}\text { } \text { IFN- } \gamma+\mathrm{CD}^{+} \mathrm{T} \text { cells } \\
\text { in males and females } \\
\text { at } 7 \text { weeks }{ }^{\ddagger}\end{array}$ & & & \\
\hline & & & & S. pneumoniae & $\begin{array}{l}\text { } \uparrow \text { IFN- } \gamma / \mathrm{LL}-10 \text { ratio in } \\
\text { females at } 18 \text { weeks }\end{array}$ & & & \\
\hline \multicolumn{9}{|c|}{$\begin{array}{l}\text { †Vaccination timings correspond to infant age at time of vaccination. } \\
\text { ¥These timings correspond to the timing before the BCG vaccination, } 1 \text { week and } 12 \text { weeks post-BCG vaccination, respectively. } \\
\text { Pam3CSK4: S)-(2,3-bis(palmitoyloxy)-(2RS)-propyl)- N-palmitoyl-(R)-Cys-(S)-Ser(S)-Lys4-OH trihydrochloride, PCV-13, Penta: Diphtheria-pertussis-tetanus-Haemophilus influenzae b- } \\
\text { HBV. Due to DiTeKiPol/Act-Hib availability issues, } 26 \text { BCG-vaccinated and } 48 \text { control infants received Infanrix Hexa. DiTeKiPol/Act-Hib contains diphtheria toxoid, TT, polio virus types } \\
\text { 1-3, H. influenzae type b polysaccharide. Infanrix Hexa also contains hepatitis B surface antigen and lower content of pertussis toxoid and aluminium [63]. } \\
\text { BP: Whole cell Bordetellla pertussis; CLO75: TLR7/8 agonist; DTP: Diphtheria-tetanus-pertussis; HBsAg: Hepatitis B surface antigen; HBV: Hepatitis B vaccine; MV: Measles vaccine; n.S.: } \\
\text { Not significant; OPV: Oral polio vaccine; PBMC: peripheral blood mononuclear cells; PHA: Phytohaemagglutinin; PMA: Phorbol myristate acetate; Polio 1-3: Poliovirus types 1-3 antigen; } \\
\text { PPD: Purified protein derivative; Prevenar 13: 13-valent pneumococcal conjugate vaccine; SEB: Staphylococcal enterotoxin B; TT: Tetanus toxoid. }\end{array}$} \\
\hline
\end{tabular}




\begin{tabular}{|c|c|c|c|c|c|c|c|}
\hline \multirow[t]{2}{*}{ Study } & \multirow[t]{2}{*}{ Vaccine schedule $^{\dagger}$} & \multirow[t]{2}{*}{ Assay } & \multirow{2}{*}{$\begin{array}{l}\text { Age at } \\
\text { observation }\end{array}$} & \multirow{2}{*}{$\begin{array}{l}\text { Secondary } \\
\text { stimulus }\end{array}$} & \multicolumn{3}{|c|}{ BCG vs control } \\
\hline & & & & & Cytokine production & $\begin{array}{l}\text { Surface } \quad \text { Proliferation } \\
\text { marker }\end{array}$ & Ref. \\
\hline \multirow[t]{5}{*}{$\begin{array}{l}\text { United } \\
\text { Kingdom }\end{array}$} & $\begin{array}{l}\text { BCG-Denmark at } \\
6 \text { weeks control - no } \\
\text { BCG }\end{array}$ & Whole blood & $\begin{array}{l}4 \text { months } \\
\text { postvaccina- } \\
\text { tion }\end{array}$ & LPS & $\begin{array}{l}\uparrow I L-8 \\
\downarrow \text { GM-CSF, GRO }\end{array}$ & & [40] \\
\hline & & & & Pam3CSK4 & $\begin{array}{l}\uparrow E G F, \text { IL-6, } \\
\text { PDGF-AB/BB, MCP-3, } \\
\text { IL-7, IL-10, IL-12p40, } \\
\text { sCD40L, eotaxin, } \\
\text { MIP-1 } \alpha\end{array}$ & $\begin{array}{l}\uparrow C D 69 \text { on NK } \\
\text { cells }\end{array}$ & \\
\hline & & & & C. albicans & $\begin{array}{l}\uparrow E G F, I L-6, \\
\text { PDGF-AB/BB, MCP-3 } \\
\downarrow I L-2, I L-13, I L-17, \text { IP-10 }\end{array}$ & & \\
\hline & & & & $\begin{array}{l}\text { Staphylococcus } \\
\text { aureus }\end{array}$ & $\uparrow E G F, I L-6, P D G F-A B / B B$ & & \\
\hline & & & & Escherichia coli & $\begin{array}{l}\uparrow \mathrm{EGF} \\
\downarrow \mathrm{GM}-\mathrm{CSF}, \mathrm{GRO}\end{array}$ & & \\
\hline Denmark & $\begin{array}{l}\text { BCG-Denmark at } \\
0-7 \text { days; } \\
\text { DiTeKiPol/Act-Hib \& \& } \\
\text { Prevenar } 13 \text { at } 3,5 \& \\
12 \text { months control - no } \\
\text { BCG }\end{array}$ & Whole blood & $\begin{array}{l}4 \text { days, } 3 \& \\
13 \text { months } \\
\text { postrandom- } \\
\text { ization to } \\
\text { BCG or } \\
\text { control } \\
\text { groups }\end{array}$ & C. albicans & $\begin{array}{l}\uparrow \text { TNF- } \alpha / \text { IL- } 10 \text { at } \\
13 \text { months }\end{array}$ & & [51] \\
\hline \multirow[t]{3}{*}{ Philippines } & $\begin{array}{l}\text { BCG at } 0-2 \text { weeks } \\
r \\
\text { BCG after the first DTP } \\
\& \text { OPV dose }\end{array}$ & PBMCs & 2-3 months & $\mathrm{TT}$ & $\begin{array}{l}\uparrow I F N-\gamma+\text { PBMCs in } \\
\text { infants vaccinated at } \\
0-2 \text { weeks }\end{array}$ & & [52] \\
\hline & & & & Polio 1-3 & $\begin{array}{l}\uparrow I F N-\gamma+\text { PBMC trend } \\
\text { in infants vaccinated at } \\
0-2 \text { weeks }\end{array}$ & & \\
\hline & & & & $\begin{array}{l}\text { PMA \& } \\
\text { ionomycin }\end{array}$ & $\begin{array}{l}\uparrow I F N-\gamma+\text { TNF- } \alpha+ \\
\text { CD45RO }+ \text { CD4 } 4^{+} \text {T cells } \\
\text { in infants vaccinated at } \\
0-2 \text { weeks }\end{array}$ & & \\
\hline \multicolumn{8}{|c|}{$\begin{array}{l}\text { †Vaccination timings correspond to infant age at time of vaccination. } \\
\text { ¥These timings correspond to the timing before the BCG vaccination, } 1 \text { week and } 12 \text { weeks post-BCG vaccination, respectively. } \\
\text { Pam3CSK4: S)-(2,3-bis(palmitoyloxy)-(2RS) -propyl)- N-palmitoyl-(R)-Cys-(S)-Ser(S)-Lys4-OH trihydrochloride, PCV-13, Penta: Diphtheria-pertussis-tetanus-Haemophilus influenzae } b- \\
\text { HBV. Due to DiTeKiPol/Act-Hib availability issues, } 26 \text { BCG-vaccinated and } 48 \text { control infants received Infanrix Hexa. DiTeKiPol/Act-Hib contains diphtheria toxoid, } T \text {, polio virus types } \\
\text { 1-3, H. influenzae type b polysaccharide. Infanrix Hexa also contains hepatitis B surface antigen and lower content of pertussis toxoid and aluminium [63]. } \\
\text { BP: Whole cell Bordetella pertussis; CL075: TLR7/8 agonist; DTP: Diphtheria-tetanus-pertussis; HBsAg: Hepatitis B surface antigen; HBV: Hepatitis B vaccine; MV: Measles vaccine; n.s.: } \\
\text { Not significant; OPV: Oral polio vaccine; PBMC: peripheral blood mononuclear cells; PHA: Phytohaemagglutinin; PMA: Phorbol myristate acetate; Polio 1-3: Poliovirus types 1-3 antigen; } \\
\text { PPD: Purified protein derivative; Prevenar 13: 13-valent pneumococcal conjugate vaccine; SEB: Staphylococcal enterotoxin B; TT: Tetanus toxoid. }\end{array}$} \\
\hline
\end{tabular}

of life [56], intensifying this process through BCG vaccination may contribute to heterologous infant protection from infectious diseases (Figure 2). However, this effect may be limited as no difference in HBsAg-specific IFN- $\gamma$ producing PBMC frequencies was found in BCG-vaccinated and control infants in Philippines [52], suggesting that BCG did not affect responses to hepatitis B vaccine in this population.

BCG may modulate heterologous responses in other T-cell populations $-C$. albicans and $S$. aureus boosted IL-17 and IL-22 production at 2 weeks and 1 year postimmunization in BCG-vaccinated adults [38]. Whole blood samples from BCG-immunized infants produced less IL-13 and IL-17 upon C. albicans stimulation at 4 months postimmunization than samples from unvaccinated controls [40]. Increased fraction of IL-2-producing, proliferating $\mathrm{CD}^{+}$Bordetella pertussis-specific T cells was found in BCG-vaccinated HIV-exposed uninfected South African infants compared with the control group [50]. This suggests that BCG may also regulate Th17, Th22 or cytotoxic T-lymphocyte subsets. It is not clear how BCG might exert this effect, but, persisting in an infant, it may prolong activation of the innate system and provide continuous cytokine signals for T-cell activation. Dendritic cells, innate lymphocytes and conventional T cells can make IL-22, while IL-1 $\beta$ or IL- 6 can promote its secretion, mediating immune responses to respiratory pathogens and fungal infections [57], implying that trained immunity 


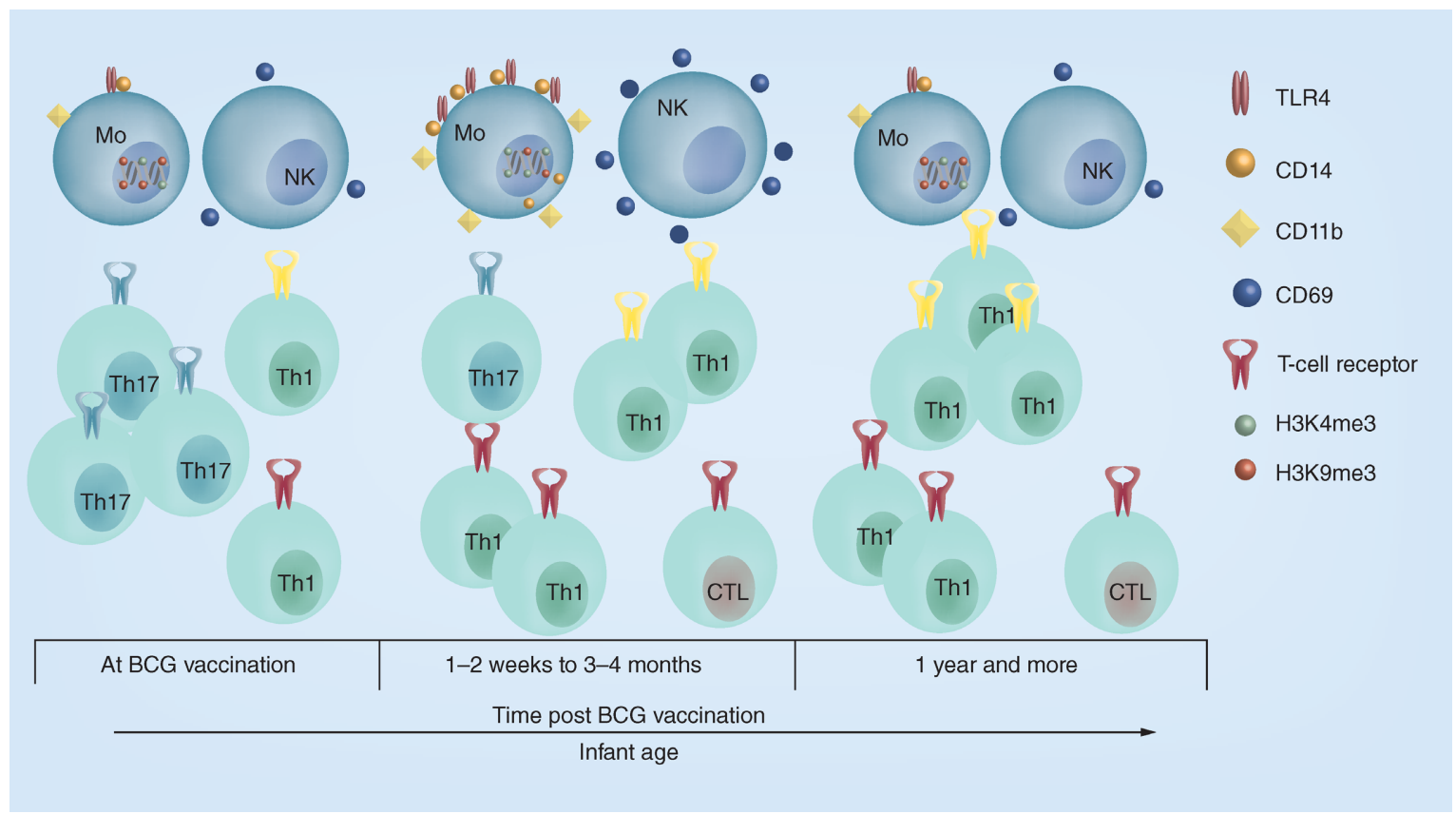

Figure 2. A model of cell populations mediating BCG-vaccinated infant heterologous responses. The diagram shows the innate and adaptive immune cells implicated in nonspecific infant protection and the likely timings for their involvement with respect to BCG vaccination and infant age. At of or immediately after BCG-vaccination, monocytes and NK cells of young infants are 'untrained', by low surface receptor expression or cytokine production. Once these cells become 'trained' by BCG, they increase surface receptor expression and inflammatory cytokine production and may cope with childhood infections more readily $[30,36,40]$. This effect diminishes over time, subsiding by 1 year postvaccination [38]. BCG, however, induces mycobacteria-specific Th1 or CTL responses [30,40]. BCG-supported heterologous T-cell responses may enhance trained innate immune responses from several weeks postimmunization and provide heterologous protection from childhood infections once trained innate immunity fades. The impact of BCG on heterologous B-cell responses is not yet clear, the current evidence being contradictive.

CTL: Cytotoxic T-cell; Mo: Monocyte; Th1: T-helper cell 1; Th17: T-helper cell 17. The role of other cells in trained immunity or heterologous adaptive responses is not well characterized yet and is therefore not presented.

and heterologous T-cell responses may complement one another mediating BCG-dependent heterologous infant protection from infections. Importantly, trained innate immunity wanes over time: PBMCs from BCG-vaccinated adults produce less TNF- $\alpha$ and IL-1 $\beta$ in response to $C$. albicans and LPS at 1 year postimmunization [38]. However, BCG-vaccinated infant protection from all-cause mortality extends for several years [4-7] or until adolescence [15]. Although improved neonatal or infancy survival can contribute to the long-term survival rates, the adaptive immune responses may take over heterologous infant protection from childhood infections once the trained immunity effect diminishes (Figure 2).

\section{Potential mechanisms beyond heterologous protection from infectious diseases \& cancer}

As well as reducing all-cause infant mortality, BCG may decrease the development of some cancers. A case-cohort study in Denmark suggested that BCG may reduce a risk of lymphoma [58]. Applied as a therapy against bladder cancer, BCG reduced patient mortality, tumor progression and recurrence for up to 10 years, however, this effect tended to decrease over time [59]. Infant protection from nonmycobacterial infections may share some mechanisms with BCG-dependent antitumor effects, with trained immunity implicated in BCG immunotherapy against bladder cancer [37]. Polymorphisms of autophagy gene $A T G 2 B$ limited the ability of BCG-trained monocytes to improve IL-1 $\beta$, IL- 6 and TNF- $\alpha$ production upon heterologous stimulation in vitro and in vivo and correlated with increased tumor progression and recurrence in bladder cancer patients treated with intravesical BCG [37]. Cytokines promoted by innate training, for example, IL-1 $\beta$, IL- 6 and TNF- $\alpha$ were suggested to mediate the anticancer effects of BCG [59], implicating overlap between BCG-mediated nonspecific protection from infectious diseases and cancer. Increased frequencies of T helper cells and IL-2, IL-12, TNF- $\alpha$, IFN- $\gamma$ and IL-10 production may also mediate the anticancer 


\begin{tabular}{|c|c|c|c|c|}
\hline Study & Vaccine schedule $^{\dagger}$ & Age at observation & BCG vs Control & Ref. \\
\hline The Gambia & $\begin{array}{l}\text { BCG-Pasteur at birth } \\
\text { or } \\
\text { BCG at } 2 \text { months } \\
\text { HBV at birth, } 2 \text { \& } 4 \text { months; } \\
\text { OPV at birth, } 1,2 \text { \& } 3 \text { months; } \\
\text { DTP at } 2,3 \text { \& } 4 \text { months control - BCG at } 4.5 \text { months }\end{array}$ & At birth, $2 \& 4$ months & $\begin{array}{l}\uparrow \alpha \mathrm{HBs} \text { at } 2 \text { and } 4.5 \text { months of age in infants } \\
\text { vaccinated with BCG at birth } \\
\uparrow \alpha \mathrm{PV} 1 \text { at } 4.5 \text { months of age in infants } \\
\text { vaccinated at } 2 \text { months of age }\end{array}$ & [48] \\
\hline Australia & $\begin{array}{l}\text { BCG-Denmark, BCG-Japan or BCG-Russia at birth; } \\
\text { HBV at birth; } \\
\text { PCV-7, Infanrix Hexa }{ }^{\ddagger} \text { \& Rota Teq }{ }^{\S} \text { at } 2,4 \text { \& } 6 \text { months; } \\
\text { control - no BCG }\end{array}$ & $\begin{array}{l}4 \text { weeks after the last } \\
\text { immunization }\end{array}$ & $\begin{array}{l}\uparrow \alpha \mathrm{Pn} \text { against serotypes } 9 \mathrm{v} \& 18 \mathrm{c} \text { trend for } \\
\uparrow \alpha \mathrm{Pn} \text { against serotype } 6 \mathrm{~b} \\
\downarrow \alpha \mathrm{HBs}\end{array}$ & [61] \\
\hline South Africa & $\begin{array}{l}\text { BCG-Denmark \& OPV at birth; } \\
\text { TETRActHib, HBV \& OPV at } 6,10 \text { \& } 14 \text { weeks; } \\
\text { MV at } 9 \text { months control - BCG at } 14 \text { weeks }\end{array}$ & 14,24 and 52 weeks & $\begin{array}{l}\text { No differences in levels of } \alpha \mathrm{Hib}, \alpha \mathrm{PT}, \alpha \mathrm{TT} \\
\text { and } \alpha \mathrm{HBs} \text { antibodies }\end{array}$ & [62] \\
\hline The Gambia & $\begin{array}{l}\text { OPV \& HBV at birth; } \\
\text { BCG-Russia at } 6 \text { weeks of age; } \\
\text { Penta I, PCV-13 \& OPV at } 8,12 \& 16 \text { weeks control - BCG } \\
\text { at } 18 \text { weeks }\end{array}$ & $6,7 \& 18$ weeks & $\begin{array}{l}\text { No differences in levels of } \alpha \mathrm{PV} 1, \alpha \mathrm{PV} 2 \text {, } \\
\alpha \mathrm{HBs}, \alpha \mathrm{DP}, \alpha \mathrm{PT} \text { and } \alpha \mathrm{TT} \text { antibodies }\end{array}$ & [31] \\
\hline Denmark & $\begin{array}{l}\text { BCG-Denmark at 0-7 days; } \\
\text { DiTeKiPol/Act-Hib\# \& Prevenar } 13 \text { at 3,5 \& } 12 \text { months } \\
\text { control - no BCG }\end{array}$ & 13 months & $\begin{array}{l}\text { No differences in levels of IgG against } \alpha \mathrm{PT} \text {, } \\
\alpha \mathrm{DP}, \alpha \mathrm{TT}, \alpha \mathrm{Hib} \text { or } \alpha \mathrm{Pn} \text { against serotypes } 4 \text {, } \\
6 \mathrm{~b}, 9 \mathrm{v}, 14,18 \mathrm{c}, 19 \mathrm{f}, 23 \mathrm{f}\end{array}$ & [63] \\
\hline \multicolumn{5}{|c|}{ 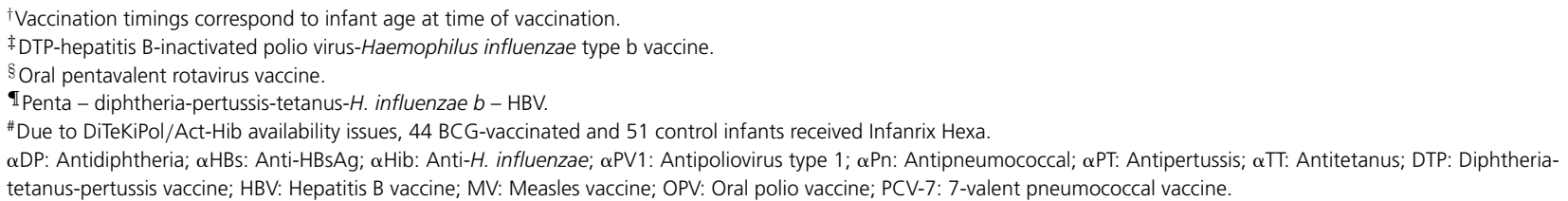 } \\
\hline
\end{tabular}

effects of BCG [58,59], suggesting the involvement of heterologous T-cell responses, similar to the observations on heterologous infant protection from infectious diseases (Table 3).

\section{Influence of BCG on humoral responses to nonmycobacterial stimuli}

Few studies explored the impact of BCG vaccination on humoral responses to heterologous antigens, however, in adults, BCG was shown to boost antibody titres against influenza vaccine [60]. Infants given BCG at birth also had higher antibody levels to HBsAg and to polio antigens than infants whose BCG vaccination was delayed (Table 4) [48]. Elevated serum antibody concentrations to pneumococcal antigens were found in BCG-immunized Australian infants compared with the control group, although, contrary to the previous findings, lower anti-HBsAg IgG levels were detected in the BCG-vaccinated group [48,61]. This study also observed a trend for increased concentrations of IgG against Haemophilus influenza and tetanus toxoid antigens [61]. Although these studies suggest BCG may have nonspecific effects on antibody production to other childhood vaccines, other findings maintain the controversy over the influence of BCG on heterologous antibody titres or function. No differences in levels of antibodies to Expanded Program for Immunization (EPI) vaccine antigens were found at 12 weeks postimmunization in BCG-vaccinated Gambian infants compared with the controls [31]. Similarly, no differences in titres of antibodies against $H$. influenza, pertussis, tetanus and hepatitis B antigens were found in South African infants immunized at birth compared with the group in which BCG immunization was delayed [62]. A recent trial in Denmark found no association between the BCG vaccination status and antibody titres against other childhood vaccine antigens at 13 months of age [63]. Possibly, timing of BCG vaccination during early immune system development phases may influence its nonspecific effects on antibody responses, as BCG may have contributed to elevated antibody titres against $H$. influenza, pertussis and several pneumococcal antigens in infants vaccinated at 2-7 days postbirth [63]; however, the extent of this effect is not clear. Variation in BCG strains, EPI vaccines or immunization schedules applied in individual studies may also influence infant humoral responses. Reducing their impact in future studies may be necessary to establish whether BCG influences antibody responses to other EPI vaccines or childhood infections. 


\section{Conclusion \& future perspective}

A large body of evidence suggests that BCG vaccination provides protection from diseases other than $\mathrm{TB}$ and that it may modulate the immune responses to other childhood vaccines. Several important implications for BCG and other vaccines that may exert similar beneficial heterologous effects arise from these findings.

First, the immunological mechanisms beyond heterologous infant protection from infectious diseases are not understood. Although BCG or other live vaccines, such as MMR vaccine may broadly enhance monocyte activation status and function or proinflammatory, Th1-polarizing responses [64], or modulate antibody responses [48,61], the data on immune mechanisms beyond heterologous infant protection from infections are inconsistent.

To overcome this, future immunological studies or randomized trials exploring the heterologous effects of BCG and their immunological mechanisms in infants may need to reduce variation in vaccination schedules or observation timings. Although this is difficult to conduct in real-life settings, it would allow for more comparability between the studies and their outcomes. In addition, despite the controversies, future studies need to address the issue of potential vaccine interactions to ensure optimal infant protection from infectious diseases.

\section{Executive summary}

All-cause infant mortality reduction

- BCG reduces all-cause infant mortality, unaccounted by reduction in mycobacterial infections alone.

Impact on acquisition of infectious diseases

- BCG may decrease the risk of nonmycobacterial sepsis and respiratory infections among the vaccinated infants.

Factors potentially contributing to the heterologous BCG effect manifestation

- Heterologous effects of BCG may be modified by interactions with other vaccines, such as diphtheria-tetanus-pertussis; however, the evidence for this is controversial.

- BCG can significantly decrease all-cause infant mortality and infectious disease acquisition in young infants; however, this effect can extend throughout childhood and adolescence.

- The sex of an infant may influence heterologous BCG protection from infectious diseases, with some studies reporting that female infants may benefit more from BCG-immunization; however, the evidence for such an effect is mixed.

Mechanisms implicated in heterologous BCG-vaccinated infant protection

- BCG may enhance maturation of infant Th1 responses and monocyte and NK cell ability to cope with a broad spectrum of pathogens for prolonged time periods.

- It may do so via innate immune training, a process characterized by metabolic, cytokine production and surface marker changes in monocytes and NK cells.

- During innate immune training with BCG, trained cells undergo a metabolic shift from oxidative phosphorylation to glycolysis.

- In parallel, changes in epigenetic regulation occur in BCG-trained cells, with accumulation of gene expression activating histone modifications accumulating at the promoters of genes encoding IL-1 $\beta$, IL- 6 and TNF- $\alpha$, glycolytic pathway components and surface receptors.

- The evidence for the presence of immunological mechanisms associated with trained immunity in BCG-vaccinated infants is mixed, with some studies reporting enhanced NK cell activation, elevated TNF- $\alpha$, IL-1 $\beta$, IL-6, IFN- $\gamma$, EGF or PDGF-AB/BB production upon heterologous stimulation; however, other studies found no association between $B C G$ immunization and heightened innate immune responses.

- Improved heterologous Th1-like responses, with increased TNF- $\alpha$ and IFN- $\gamma$ production in response to Expanded Program for Immunization vaccine antigens were reported in multiple sites, including Uganda, Guinea-Bissau, The Gambia or Philippines.

- As BCG-vaccinated individual IL-1 $\beta$ and TNF- $\alpha$ production in response to innate immunity stimuli subsides by 1 year postimmunization, heterologous BCG-dependent T-cell activation can contribute to or maintain nonspecific BCG effects once trained immunity benefits wane.

- BCG may modulate infant humoral responses to other immunizations, elevating or decreasing antibody levels to such vaccines as hepatitis B or pneumococcal conjugate vaccines; however, further studies are needed to determine the extent of this effect.

Conclusion \& future perspective

- Multiple epidemiological and immunological studies confirm that BCG exerts broad, beneficial effects in the vaccinated individuals protecting them from diseases other than TB.

- Trained immunity enhanced heterologous T-cell responses and, possibly, modulated antibody responses to other vaccines may mediate the nonspecific effects of BCG.

- Further work is needed to address the role of these factors on BCG and other childhood vaccine dependent heterologous effects and define the underlying mechanisms. 
Further work needs to address how BCG or other childhood immunizations regulate T- and B-cell subsets of diverse antigen specificities and which memory or effector cell fractions they maintain or promote to proliferate. In parallel, the role of the innate immune responses in mediating the nonspecific effects of BCG, MMR or other vaccines needs to be studied more extensively. It would also be interesting to test if other cell types could be involved in heterologous infant protection from all-cause mortality or infections. Together, this knowledge may be exploited for improving anti-TB and other childhood vaccine design.

\section{Financial \& competing interests disclosure}

E Butkeviciute is supported by a London Intercollegiate Doctoral Training Programme studentship funded by the MRC. CE Jones has received funding from the IMmunising PRegnant women and INfants neTwork (IMPRINT), funded by the GCRF Networks in Vaccines Research and Development, which was co-funded by the MRC and BBSRC; the National Vaccine Program Office (NVPO) and Bill \& Melinda Gates Foundation, Grant OPP1119788, Global Alignment of Immunization Safety Assessment in pregnancy (GAIA). CE Jones is an investigator for clinical trials performed on behalf of the University of Southampton and University Hospital Southampton NHS Trust, UK, sponsored by vaccine manufacturers, including Novavax, GSK and Janssen. She has received no personal funding for these activities. SG Smith is supported by a grant awarded to Prof. Hazel M. Dockrell by the European Commission within Horizon2020 TBVAC2020 (Grant No. H2020 PHC-643381) and by the GCRF Networks in Vaccines Research and Development VALIDATE Network which was co-funded by the MRC and BBSRC (Grant No. MR/R005850/1). The authors have no other relevant affiliations or financial involvement with any organization or entity with a financial interest in or financial conflict with the subject matter or materials discussed in the manuscript apart from those disclosed.

No writing assistance was utilized in the production of this manuscript.

\section{Open access}

This work is licensed under the Attribution-NonCommercial-NoDerivatives 4.0 Unported License. To view a copy of this license, visit http://creativecommons.org/licenses/by-nc-nd/4.0/

\section{References}

Papers of special note have been highlighted as: $\bullet$ of interest; $\bullet \bullet$ of considerable interest

1. Trunz BB, Fine PEM, Dye C. Effect of BCG vaccination on childhood tuberculous meningitis and miliary tuberculosis worldwide: a meta-analysis and assessment of cost-effectiveness. Lancet 367(9517), 1173-1180 (2006).

2. Colditz GA, Brewer TF, Berkey CS et al. Efficacy of BCG vaccine in the prevention of tuberculosis. Meta-analysis of the published literature. JAMA 271(9), 698-702 (1994).

3. Mangtani P, Abubakar I, Ariti C et al. Protection by BCG vaccine against tuberculosis: a systematic review of randomized controlled trials. Clin. Infect. Dis. 58(4), 470-480 (2014).

4. Kristensen I, Aaby P, Jensen H. Routine vaccinations and child survival: follow up study in Guinea-Bissau, West Africa. BMJ 321(7274), 1435-1438 (2000).

- This early epidemiological study demonstrated that BCG and other childhood vaccines can exert nonspecific effects on overall infancy survival and attracted scientific interest in this phenomenon.

5. Vaugelade J, Pinchinat S, Guiella G, Elguero E, Simondon F. Non-specific effects of vaccination on child survival: prospective cohort study in Burkina Faso. BMJ 329(7478), 1309 (2004).

6. Elguero E, Simondon KB, Vaugelade J, Marra A, Simondon F. Non-specific effects of vaccination on child survival? A prospective study in Senegal. Trop. Med. Int. Health 10(10), 956-960 (2005).

7. Nankabirwa V, Tumwine JK, Mugaba PM, Tylleskär T, Sommerfelt H. Child survival and BCG vaccination: a community based prospective cohort study in Uganda. BMC Public Health 15(1), 175 (2015).

8. Aaby P, Roth A, Ravn H et al. Randomized trial of BCG vaccination at birth to low-birth-weight children: beneficial nonspecific effects in the neonatal period? J. Infect. Dis. 204(2), 245-252 (2011).

9. Moulton LH, Rahmathullah L, Halsey NA, Thulasiraj RD, Katz J, Tielsch JM. Evaluation of non-specific effects of infant immunizations on early infant mortality in a southern Indian population. Trop. Med. Int. Health 10(10), 947-955 (2005).

10. Aaby P, Vessari H, Nielsen J et al. Sex differential effects of routine immunizations and childhood survival in rural Malawi. Pediatr. Infect. Dis. J. 25(8), 721-727 (2006).

11. Biering-Sørensen S, Aaby P, Napirna BM et al. Small randomized trial among low-birth-weight children receiving bacillus Calmette-Guérin vaccination at first health center contact. Pediatr. Infect. Dis. J. 31(3), 306-308 (2012).

12. Higgins JP, Soares-Weiser K, Lopez-Lopez JA et al. Association of BCG, DTP, and measles containing vaccines with childhood mortality: systematic review. BMJ 355(i5170), 1-13 (2016). 
- This recent review provides an excellent overview of epidemiological studies on nonspecific effects of BCG, diphtheria-tetanus-pertussis and measles vaccines.

13. Higgins JP, Soares-Weiser K, Reingold A. Systematic review of the non-specific effects of BCG, DTP and measles containing vaccines. WHO SAGE Report 1-34 (2014).

www.who.int/immunization/sage/meetings/2014/april/3_NSE_Epidemiology_review_Report_to_SAGE_14_Mar_FINAL.pdf

- This systematic review presents a detailed analysis and discussion of epidemiological studies on the non-specific effects of BCG, Diphtheria-tetanus-pertussis and measles vaccines and discusses factors suggested to modulate the extent of heterologous vaccine effects.

14. Elliott AM, Nakiyingi J, Quigley MA, French N, Gilks CF, Whitworth JA. Inverse association between BCG immunisation and intestinal nematode infestation among HIV-1-positive individuals in Uganda. Lancet 354(9183), 1000-1001 (1999).

15. De Castro MJ, Pardo-Seco J, Martinón-Torres F. Nonspecific protection of neonatal BCG vaccination against hospitalization due to respiratory infection and sepsis. Clin. Infect. Dis. 60(11), 1611-1619 (2015).

16. Hollm-Delgado M-G, Stuart EA, Black RE. Acute lower respiratory infection among Bacille Calmette-Guérin-vaccinated children. Pediatrics 133(1), e73-e81 (2014).

17. Kjaergaard J, Birk NM, Nissen TN et al. Nonspecific effect of BCG vaccination at birth on early childhood infections: a randomized, clinical multicenter trial. Pediatr. Res. 80(5), 681-685 (2016).

18. Stensballe LG. Does BCG have non-specific effects on childhood mortality? BMJ 356, j700 (2017).

19. Chan GJ, Moulton LH, Becker S, Muñoz A, Black RE. Non-specific effects of diphtheria-tetanus-pertussis vaccination on child mortality in Cebu, The Philippines. Int. J. Epidemiol. 36(5), 1022-1029 (2007).

20. Aaby P, Benn CS, Nielsen J, Ravn H. Sex-differential non-specific effects of BCG and DTP in Cebu, The Philippines. Int. J. Epidemiol. 38(1), 320-323 (2009).

21. Aaby P, Nielsen J, Benn CS, Trape J-F. Sex-differential and non-specific effects of routine vaccinations in a rural area with low vaccination coverage: an observational study from Senegal. Trans. R. Soc. Trop. Med. Hyg. 109(1), 77-84 (2015).

22. Aaby P, Benn C, Nielsen J, Lisse IM, Rodrigues A, Ravn H. Testing the hypothesis that diphtheria-tetanus-pertussis vaccine has negative non-specific and sex-differential effects on child survival in high-mortality countries. BMJ Open 2(3), 1-24 (2012).

23. Roth AE, Stabell Benn C, Ravn H et al. Effect of revaccination with BCG in early childhood on mortality: randomised trial in Guinea-Bissau. BMJ 340, 1-11 (2010).

24. Hirve S, Bavdekar A, Juvekar S, Benn CS, Nielsen J, Aaby P. Non-specific and sex-differential effects of vaccinations on child survival in rural western India. Vaccine 30(50), 7300-7308 (2012).

25. Roth A, Gustafson P, Nhaga A et al. BCG vaccination scar associated with better childhood survival in Guinea-Bissau. Int. J. Epidemiol. 34(3), 540-547 (2005).

26. Roth A, Sodemann M, Jensen H et al. Tuberculin reaction, BCG scar, and lower female mortality. Epidemiology 17(5), 562-568 (2006).

27. Aaby $\mathrm{P}$, Jensen $\mathrm{H}$, Walraven $\mathrm{G}$. Age-specific changes in the female-male mortality ratio related to the pattern of vaccinations: an observational study from rural Gambia. Vaccine 24(22), 4701-4708 (2006).

28. Aaby $\mathrm{P}$, Jensen $\mathrm{H}$, Rodrigues A et al. Divergent female-male mortality ratios associated with different routine vaccinations among female-male twin pairs. Int. J. Epidemiol. 33(2), 367-373 (2004).

29. Krishnan A, Srivastava R, Dwivedi P, Ng N, Byass P, Pandav CS. Non-specific sex-differential effect of DTP vaccination may partially explain the excess girl child mortality in Ballabgarh, India. Trop. Med. Int. Health 18(11), 1329-1337 (2013).

30. Jensen KJ, Larsen N, Biering-Sørensen S et al. Heterologous immunological effects of early BCG vaccination in low-birth-weight infants in Guinea-Bissau: a randomized-controlled trial. J. Infect. Dis. 211(6), 956-967 (2015).

- This clinical study bridges epidemiological observations on BCG-dependent heterologous infectious disease protection in infants and trained innate immunity.

31. Darboe F, Adetifa JU, Reynolds J et al. Minimal sex-differential modulation of reactivity to pathogens and toll-like receptor ligands following infant bacillus Calmette-Guérin Russia vaccination. Front. Immunol. 8(1092), 1-13 (2017).

32. Shann F. Nonspecific effects of vaccines and the reduction of mortality in children. Clin. Ther. 35(2), 109-114 (2013).

33. Sankoh O, Welaga P, Debpuur C et al. The non-specific effects of vaccines and other childhood interventions: the contribution of INDEPTH Health and Demographic Surveillance Systems. Int. J. Epidemiol. 43(3), 645-653 (2014).

34. Levy O, Levy O. Ready to benefit from training: heterologous effects of early life immunization. Trans. R. Soc. Trop. Med. Hyg. 109(1), 3-4 (2015).

35. Van't Wout JW, Poell R, Van Furth R. The role of BCG/PPD-activated macrophages in resistance against systemic candidiasis in mice. Scand. J. Immunol. 36(5), 713-720 (1992).

36. Kleinnijenhuis J, Quintin J, Preijers F et al. Bacille Calmette-Guerin induces NOD2-dependent nonspecific protection from reinfection via epigenetic reprogramming of monocytes. Proc. Natl Acad. Sci. USA 109(43), 17537-17542 (2012). 
-• This immunological study was among the first to show that BCG may induce long-term epigenetic and functional changes in the innate immune cells in vitro and in vivo.

37. Buffen K, Oosting M, Quintin J et al. Autophagy controls BCG-induced trained immunity and the response to intravesical BCG therapy for bladder cancer. PLoS Pathog. 10(10), 1-10 (2014).

38. Kleinnijenhuis J, Quintin J, Preijers F et al. Long-lasting effects of BCG vaccination on both heterologous Th1/Th17 responses and innate trained immunity. J. Innate Immun. 6(2), 152-158 (2014).

39. Kleinnijenhuis J, Quintin J, Preijers F et al. BCG-induced trained immunity in NK cells: role for non-specific protection to infection. Clin. Immunol. 155(2), 213-219 (2014).

40. Smith SG, Kleinnijenhuis J, Netea MG, Dockrell HM. Whole blood profiling of Bacillus Calmette-Guérin-Induced trained innate immunity in infants identifies epidermal growth factor, IL-6, platelet-derived growth factor-AB/BB, and natural killer cell activation. Front. Immunol. 8, 1-11 (2017).

41. Arts RJW, Carvalho A, La Rocca C et al. Immunometabolic pathways in BCG-induced trained immunity. Cell Rep. 17(10), 2562-2571 (2016).

42. Arts RJW, Blok BA, Aaby P et al. Long-term in vitro and effects of $\gamma$-irradiated BCG on innate and adaptive immunity. J. Leukoc. Biol. 98(6), 995-1001 (2015).

43. Arts RJW, Blok BA, Van Crevel R et al. Vitamin A induces inhibitory histone methylation modifications and down-regulates trained immunity in human monocytes. J. Leukoc. Biol. 98(1), 129-136 (2015).

44. Cheng S-C, Quintin J, Cramer RA et al. mTOR- and HIF-1 $\alpha$-mediated aerobic glycolysis as metabolic basis for trained immunity. Science 345(6204), 1250684 (2014).

45. Bekkering S, Blok BA, Joosten LA, Riksen NP, Van Crevel R, Netea MG. In vitro experimental model of trained innate immunity in human primary monocytes. Clin. Vaccine Immunol. 23(12), 926-933 (2016).

46. Bekkering S, Quintin J, Joosten LA, Van Der Meer JW, Netea MG, Riksen NP. Oxidized low-density lipoprotein induces long-term proinflammatory cytokine production and foam cell formation via epigenetic reprogramming of monocytes. Arterioscler. Thromb. Vasc. Biol. 34(8), 1731-1738 (2014).

47. Lovewell RR, Sassetti CM, Vanderven BC. Chewing the fat: lipid metabolism and homeostasis during M. tuberculosis infection. Curr. Opin. Microbiol. 29, 30-36 (2016).

48. Ota MOC, Vekemans J, Schlegel-Haueter SE et al. Influence of Mycobacterium bovis bacillus Calmette-Guérin on antibody and cytokine responses to human neonatal vaccination. J. Immunol. 168(2), 919-925 (2002).

-• This early immunological work demonstrated that BCG-immunization may boost heterologous T- and B-cell responses to Expanded Program for Immunization vaccines in infants.

49. Anderson EJ, Webb EL, Mawa PA et al. The influence of BCG vaccine strain on mycobacteria-specific and non-specific immune responses in a prospective cohort of infants in Uganda. Vaccine 30(12), 2083-2089 (2012).

50. Blakney AK, Tchakoute CT, Hesseling AC et al. Delayed BCG vaccination results in minimal alterations in T cell immunogenicity of acellular pertussis and tetanus immunizations in HIV-exposed infants. Vaccine 33(38), 4782-4789 (2015).

51. Nissen TN, Birk NM, Blok BA et al. Bacillus Calmette-Guérin vaccination at birth and in vitro cytokine responses to non-specific stimulation. A randomized clinical trial. Eur. J. Clin. Microbiol. Infect. Dis. 37(1), 29-41 (2017).

52. Libraty DH, Zhang L, Woda $\mathrm{M}$ et al. Neonatal BCG vaccination is associated with enhanced T-helper 1 immune responses to heterologous infant vaccines. Trials Vaccinol. 3, 1-5 (2014).

53. Mawa PA, Webb EL, Filali-Mouhim A et al. Maternal BCG scar is associated with increased infant proinflammatory immune responses. Vaccine 35(2), 273-282 (2017).

54. Prentice S, Jallow MW, Prentice AM. The effect of BCG on iron metabolism in the early neonatal period: a controlled trial in Gambian neonates. Vaccine 33(26), 2963-2967 (2015).

55. Mathurin KS, Martens GW, Kornfeld H, Welsh RM. CD4 T-cell-mediated heterologous immunity between mycobacteria and poxviruses. J. Virol. 83(8), 3528-3539 (2009).

56. Kollmann TR, Levy O, Montgomery RR, Goriely S. Innate immune function by Toll-like receptors: distinct responses in newborns and the elderly. Immunity 37(5), 771-783 (2012).

57. Mcaleer JP, Kolls JK. Directing traffic: IL-17 and IL-22 coordinate pulmonary immune defense. Immunol. Rev. 260(1), 129-144 (2014).

58. Villumsen M, Sørup S, Jess T et al. Risk of lymphoma and leukaemia after bacille Calmette-Guérin and smallpox vaccination: a Danish case-cohort study. Vaccine 27(49), 6950-6958 (2009).

59. Gandhi NM, Morales A, Lamm DL. Bacillus Calmette-Guérin immunotherapy for genitourinary cancer. BJU Int. 112(3), 288-297 (2013).

60. Leentjens J, Kox M, Stokman R et al. BCG vaccination enhances the immunogenicity of subsequent influenza vaccination in healthy volunteers: a randomized, placebo-controlled pilot study. J. Infect. Dis. 212(12), 1930-1938 (2015). 
61. Ritz N, Mui M, Balloch A, Curtis N. Non-specific effect of bacille Calmette-Guérin vaccine on the immune response to routine immunisations. Vaccine 31(30), 3098-3103 (2013).

62. Hesseling AC, Blakney AK, Jones CE et al. Delayed BCG immunization does not alter antibody responses to EPI vaccines in HIV-exposed and -unexposed South African infants. Vaccine 34(32), 3702-3709 (2016).

63. Nissen TN, Birk NM, Smits G et al. Bacille Calmette-Guérin vaccination at birth and antibody responses to childhood vaccines. A randomised clinical trial. Vaccine 35(16), 2084-2091 (2017).

64. Nicoli F, Appay V. Immunological considerations regarding parental concerns on pediatric immunizations. Vaccine 35(23), 3012-3019 (2017). 